\title{
Alteration in the Doxorubicin-Induced DNA Damage in Cultured V79 Cells by Aegle marmelos (L.) Correa (Bael): A Comet Assay Study
}

Ganesh Chandra Jagetia* and Ponemone Venkatesh

Department of Zoology, Mizoram University, Tanhril, Aizawl-796 004, Mizoram, India

"Corresponding author: Ganesh Chandra Jagetia, Department of Zoology, Mizoram University, Tanhril, Aizawl-796 004, Mizoram, India, Tel: 011-389-2330514; Fax: 011-389-233227; E-mail: gc.jagetia@gmail.com

Received date: Nov 23, 2015; Accepted date: Dec 21, 2015; Published date: Dec 28, 2015

Copyright: ( 2015 Jagetia GC, et al. This is an open-access article distributed under the terms of the Creative Commons Attribution License, which permits unrestricted use, distribution, and reproduction in any medium, provided the original author and source are credited

\begin{abstract}
The clinical applicability of wide spectrum chemotherapeutic drug, doxorubicin is limited due to induction of severe cardiomyopathy resulting from DNA damage. The present study was aimed to evaluate the protective effect of bael (Aegle marmelos) extract (AME) on the doxorubicin-induced molecular DNA damage in V79 cells. V79 (Chinese hamster lung fibroblasts) cells were treated with 0 or $25 \mu \mathrm{g} / \mathrm{ml} \mathrm{AME}$ before exposure to $0,1,2.5,5,10,25$ or $50 \mu \mathrm{g} / \mathrm{ml}$ doxorubicin DOX. The DNA damage was studied at different post-doxorubicin treatment times using single cell gel electrophoresis. Doxorubicin caused a maximum DNA damage at $1 \mathrm{~h}$ post-DOX treatment indicated by a highest Olive Tail Movement (OTM) and tail DNA, whereas treatment of V79 cells with $25 \mu \mathrm{g} / \mathrm{ml}$ AME enhanced DNA repair at all assessment times with a maximum repair up to $8 \mathrm{~h}$ which did not alter thereafter. In another experiment DOX caused a concentration dependent increase in the DNA damage and treatment of V79 cells with 25 $\mu \mathrm{g} / \mathrm{ml}$ AME significantly inhibited DOX-induced DNA damage at all post-DOX treatment times. The rate of DNA repair was higher in AME pre-treated cells than DOX-treatment alone. Assessment of cell survival showed a concentration dependent decline in the clonogenicity after DOX-treatment, whereas AME pre-treatment arrested the DOX-induced reduction in the cell survival. The DNA damage and clonogenicity of cells showed a close but inverse relationship, i.e., with increasing DNA damage there was a corresponding reduction in the cell survival. This relationship between cell survival and DNA damage was linear quadratic. Our study demonstrates that AME pretreatment reduced the DOX-induced DNA damage and hastened the DNA repair in V79 cells, thus demonstrating the chemoprotective potential of AME.
\end{abstract}

Keywords: V79 Cells; Aegle marmelos, Doxorubicin; DNA damage, Comet assay; Cell survival

\section{Introduction}

Doxorubicin (adriamycin), an antibiotic having a wide spectrum of anti-neoplastic activity was isolated from the cultures of mutant fungus, Streptomyces peucetius caesius [1]. It has been found to be active against several solid neoplasms [2], Hodgkin's disease, leukemias, lymphomas [3] and rat tumors [4]. Despite the fact that doxorubicin is active against several tumors it causes severe cardiomyopathy limiting its clinical use [5]. Doxorubicin has been reported to induce micronuclei, chromatid and chromosome aberrations, DNA single and double strand breaks in vitro and in vivo [6-15]. In an attempt to control neoplastic disorders and distant metastases the chemotherapeutic agents are administered systemically, which adversely affects the DNA of other normal cells leading to genotoxicity and subsequently producing second malignancies $[16,17]$. Since doxorubicin is a wide spectrum chemotherapeutic drug, reduction in its toxicity will be beneficial in the better management of neoplasia and benefit the patients receiving doxorubicin therapy.

If the potential of doxorubicin has to be fully utilized in the treatment of cancer, its toxicity needs to be reduced. The use of antioxidants to reduce doxorubicin-induced toxicity has been advocated. The strategies have been devised to prevent doxorubicininduced cardiotoxicity without affecting its antitumor activity by combining it with cardioprotective agents and antioxidants $[18,19]$.
Dexazoxane, a bisdioxopiperazine compound is a clinically approved as a prophylaxis for the doxorubicin-induced cardiotoxicity in cancer patients [20]. Other agents like venoruton (a standardized mixture of flavonoids), propolis (bee glue) and many other natural antioxidants were clinically evaluated for their cardioprotective efficacy, but with limited success [21]. Recently, intensive researches on biological function of natural antioxidants to reduce doxorubicin-induced toxicity have been carried out with numerous plant materials worldwide, including those used as foods $[15,22,23]$. It is also well known that natural antioxidants, including phenolic or thiolic compounds could protect against damages caused by reactive oxidants by various biological mechanisms in living cells [22-25].

The antiquity of use of plants to treat various ailments in humans is as old as the human civilization. The Indian system of medicine, the Ayurveda gives a detailed account of the medicinal properties of numerous plants and their use to treat various disorders in humans. These plant-based systems continue to play an important role in healthcare and it has been estimated by the World Health Organization that approximately $80 \%$ of human population globally rely mainly on the traditional medicines for their primary healthcare [26]. Therefore, a need is felt to find alternative drugs to synthetic drugs, which could reduce and repair the deleterious effects of doxorubicin-induced DNA damage. This can be achieved by screening newer molecules or plant products, which may be effective at non-toxic dose levels.

Aegle marmelos, commonly known as bael, is a spinous tree belonging to family Rutaceae. Its edible leaf, root, bark, seeds and fruits are also valued in Ayurvedic medicine in India [27]. In fact as per 
Charaka (1500 BC) no drug has been longer or better known or appreciated by the inhabitants of India than bael [28]. Its leaves are astringent, laxative, febrifuge, and expectorant and are useful in ophthalmia, deafness, inflammations, catarrh, diabetes, asthmatic complaints and weakness of heart. The unripe fruit is bitter, acrid, sour, astringent, aids in digestion and stomach irritation, and are useful in treating diarrhoea, dysentery, and stomachalgia. Roots are used as an ingredient in dhasmula (ten roots), a medicine commonly used by Ayurvedic practitioners. Fresh aqueous and alcoholic leaf extracts of bael are reported to have a cardiotonic effect similar to digitalis and decrease the requirement of circulatory stimulants [29,30]. Bael pretreatment has been reported to increase the activities of superoxide dismutase, Catalase and glutathione peroxidase in the liver and intestine of irradiated mice $[31,32]$. Our earlier studies have shown that bael protected against the radiation and DOX-induced micronuclei in a concentration dependent manner in cultured human lymphocytes, V79 cells and mice bone marrow cells [14,15,33]. It also protected the mice against doxorubicin-induced cardiotoxicity [19]. However, the mechanism of action of AME in protecting against the DOX-induced toxicity remains to be elucidated.

The comet assay (single-cell gel electrophoresis) is a simple method of measuring molecular DNA damage in the eukaryotic cells efficiently, where cells are embedded in agarose on a microscope slide, lysed with detergent and high salt so as to form nucleoids containing supercoiled loops of DNA linked to the nuclear matrix. Electrophoresis of these embedded cells at high $\mathrm{pH}$ results in structures resembling comets, observed by fluorescence microscopy. The intensity of the comet tail relative to the head of comets reflects the number of DNA breaks [34]. The comet assay has found its utility in testing novel chemicals for genotoxicity, monitoring environmental contamination with genotoxins, human biomonitoring, cancer biology, molecular epidemiology, and fundamental research in DNA damage and repair. The sensitivity and specificity of the assay are greatly enhanced if the nucleoids are incubated with bacterial repair endonucleases that recognize specific kinds of damage in the DNA and convert lesions into DNA breaks, thus increasing the amount of DNA in the comet tail. DNA repair can be monitored by incubating cells after treatment with damaging agent and measuring the DNA damage remaining at different intervals. The alkaline comet assay can detect double and single strand breaks, alkali-labile sites that are expressed as single strand breaks and single strand breaks associated with incomplete excision repair [35]. The use of comet assay may be helpful in assessing DNA damage at molecular level and ascertain the chemoprotective effect of bael. Therefore, the present study was undertaken to obtain an insight into the protective effect of bael on the cell survival and DNA damage by comet assay in cultured V79 cells exposed to different concentrations of DOX.

\section{Materials and Method}

\section{Preparation of extract}

The identification of Aegle marmelos (L.) Correa, family, Rutaceae was carried by Dr. Gopal Krishna Bhat (a well-known taxonomist), Department of Botany, Poorna Prajna College, Udupi, India and the herbarium specimen No.AG 032 is stored with us. The mature leaves of Aegle marmelos was collected locally during the month of April-May of the year, cleaned, shade dried and powdered. One hundred grams of the leaf powder was extracted with $50 \%$ ethanol in a Soxhlet apparatus. The extract was freeze-dried and stored at $-80^{\circ} \mathrm{C}$ until further use. An approximate yield of $24 \%$ was obtained. Henceforth the bael extract will be called as AME.

\section{Drug and chemicals}

Doxorubicin hydrochloride (Adriamycin) was procured from Biochem Pharmaceutical Industries, Mumbai, India. Normal and low melting agarose (Cat No. A-4718), ethylenediamine tertra acetic acid (EDTA), Minimum essential medium (MEM), fetal calf serum, Lglutamine and gentamycin sulfate, trizama base, ethidium bromide and triton X-100 were procured from Sigma Chemical Co. St. Louis, USA. The other routine chemicals were procured from Ranbaxy fine Chemicals, Mumbai, India.

\section{Preparation of drug}

Doxorubicin hydrochloride (DOX) and AME were dissolved in MEM immediately before use.

\section{Cell line and culture}

V79, Chinese hamster lung fibroblasts, procured from the National Centre for Cell Sciences, Pune, India, have been used throughout the study. The cells were routinely grown in $75-\mathrm{cm}^{2}$ flasks (Falcon, Becton Dickinson, USA) with loosened caps, containing Eagle's minimum essential medium (MEM) supplemented with $10 \%$ fetal calf serum, $1 \%$ L-glutamine and $50 \mu \mathrm{g} / \mathrm{ml}$ gentamycin sulfate at $37^{\circ} \mathrm{C}$ in a $\mathrm{CO}_{2}$ incubator (NuAire, Plymouth, MN, USA) in an atmosphere of humidified $5 \% \mathrm{CO}_{2}$ in $95 \%$ air.

\section{Experimental design}

A fixed number $\left(5 \times 10^{5}\right)$ of exponentially growing cells inoculated into several individual culture flasks or embedded in agarose were divided into following groups:-

\section{MEM+DOX}

The cell cultures were incubated with DOX for $1 \mathrm{~h}$, thereafter the drug containing media was replaced with a fresh drug-free MEM.

\section{AME + DOX}

The cultures of this group were treated with $25 \mu \mathrm{g} / \mathrm{ml}$ of AME for 1 $\mathrm{h}$ [15] and the AME containing media were replaced with MEM containing various concentrations of DOX for another $1 \mathrm{~h}$.

\section{Cell survival}

Clonogenicity of cells was measured using colony-forming assay of Puck and Marcus [36]. The log phase cells were treated with $25 \mu \mathrm{g} / \mathrm{ml}$ AME for $1 \mathrm{~h}$ before exposure to $0,1,2.5,5,10,25$ or $50 \mu \mathrm{g} / \mathrm{ml}$ DOX. One hour after the DOX treatment, the drug-containing medium was removed and the cells were washed twice with sterile PBS. The cells from each group of flasks were dislodged by trypsin EDTA treatment. Usually, 200 to 300 cells were inoculated into $25 \mathrm{~cm}^{2}$ culture dishes (Nunc, Denmark) containing $5 \mathrm{ml}$ medium in triplicate for each drug concentration for each group. The cells were allowed to grow for 9 days and the resultant colonies were stained with $1 \%$ crystal violet in methanol. The clusters containing 50 or more cells were scored as a colony. The plating efficiency of cells was determined and the surviving fraction was calculated and fitted on to non-linear polynomial functions. 


\section{DNA damage detection by comet assay}

Since DOX acts on DNA, it was decided to investigate the effect of AME on the DOX-induced molecular damage to DNA by employing single cell gel electrophoresis (comet assay) in alkaline condition, where two individual experiments were carried out to study the effect of AME on the of DOX-induced damage as described below.

\section{DNA repair}

The alteration in the DOX-induced DNA damage repair kinetics by AME was evaluated by single cell gel electrophoresis (comet assay). Exponentially growing V79 cells were incubated with MEM or 25 $\mu \mathrm{g} / \mathrm{ml}$ of AME for $1 \mathrm{~h}$, washed, and then incubated in the medium with $10 \mu \mathrm{g} / \mathrm{ml}$ of DOX for $1 \mathrm{~h}$ at $37^{\circ} \mathrm{C}$. To examine DNA repair kinetics at different times, the cells from both groups were washed twice and resuspended in fresh, drug-free medium. Aliquots of suspension from DOX treatment alone or AME+DOX groups were taken immediately at $0,1 / 2,1,2,4,6,12,16$ and $24 \mathrm{~h}$ post-DOX treatment and kept in an ice bath to stop the DNA repair.

\section{DNA damage response}

An another experiment was carried out to study the effect of 25 $\mu \mathrm{g} / \mathrm{ml}$ AME on the DNA damage caused by different concentrations of DOX, where V79 cells were pre-treated with or without AME for $1 \mathrm{~h}$, washed, and then incubated in medium containing $0,1,2.5,5,10,25$ or $50 \mu \mathrm{g} / \mathrm{ml}$ DOX for $1 \mathrm{~h}$ at $37^{\circ} \mathrm{C}$. Thereafter, the cells were washed twice and replaced with drug free medium. The cell cultures were terminated at 1, 4 or $6 \mathrm{~h}$ and the cells were collected and kept on ice bath for comet assay.

\section{Alkaline comet assay}

The single cell gel electrophoresis or comet assay is usually carried out by embedding cells in agarose, followed by lysis in an alkaline/ neutral buffer. The application of electric current pulls the charged DNA out of the nucleus, where relaxed and damaged DNA fragments migrate away from the confines of the nucleus than intact DNA, which looks like the comet [Figure 1].
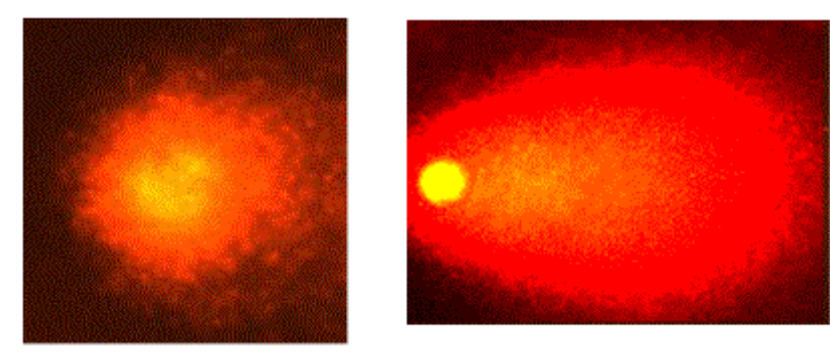

Figure 1: Representative comet images of V79 cells exposed to doxorubicin. Left: undamaged cells and Right: Comet image of adoxorubicin treated cell.

The images are captured and the extent of DNA damage can be precisely determined [34,37-39]. The comet assay was performed under alkaline conditions essentially according to the procedure of Singh et al. [37] with minor modifications [40]. The slides frosted at one side were covered with $100 \mu \mathrm{l}$ of $0.6 \%$ low melting agarose (SigmaAldrich Co., St. Louis, USA; Cat No. A-4718) prepared in Ca- and Mg- free PBS at $37^{\circ} \mathrm{C}$ and the agarose was allowed to solidify under a cover slip on ice after which the cover slips were removed. One $\mathrm{ml}$ aliquots containing $1 \times 10^{5}$ harvested V79 cells in culture medium were centrifuged at $1,500 \mathrm{rpm}$ for $5 \mathrm{~min}$. The pelleted cells were resuspended in $80 \mu \mathrm{l}$ of $0.6 \%$ low melting agarose layered on to the first layer and allowed to solidify under a cover slip on ice. All the steps were conducted under a reduced light to prevent additional DNA damage.

The slides containing V79 cells and embedded in agarose were placed into cold lysis buffer $(2.5 \mathrm{M} \mathrm{NaCl}, 100 \mathrm{mM}$ Na2EDTA, $10 \mathrm{mM}$ and Trizma base, $\mathrm{pH} 10$ with freshly added 1\% Triton X-100) for $2 \mathrm{~h}$. This removed cellular proteins and left the DNA as nucleoids, thereafter the cell lysis buffer was drained from the slides. The slides containing cells were placed into a horizontal gel electrophoresis tank containing fresh alkaline ( $\mathrm{pH} 13)$ electrophoresis buffer $(300 \mathrm{mM}$ $\mathrm{NaOH}, 1 \mathrm{mM}$ Na2EDTA). The level of buffer was kept $\sim 0.25 \mathrm{~cm}$ above the slides, which were kept in this condition for $20 \mathrm{~min}$ to allow unwinding of DNA. The electrophoresis was run for $20 \mathrm{~min}$ at $1.25 \mathrm{~V}$ $\mathrm{cm}^{-1}$ and $300 \mathrm{~mA}$ in cold environment. The alkaline buffer was drained of from the slides, which were subsequently flooded slowly with neutralization buffer ( $0.4 \mathrm{M}$ Trizma base, $\mathrm{pH} 7.5)$ for $5 \mathrm{~min}$ each three times. The slides were stained with $50 \mu \mathrm{l}$ of ethidium bromide $(2 \mathrm{mg} /$ $\mathrm{ml}$ ), covered with a coverslip and analyzed immediately.

The ethidium bromide stained DNA on each slide was visualized as "comets" with a fluorescent head and a tail at 40X magnification using an epifluorescence microscope (Olympus BX51, Olympus Microscopes, Tokyo, Japan) equipped with a 515-535 nm excitation filter, and a $590 \mathrm{~nm}$ barrier filter. The comet images were acquired using a CCD camera (CoolSNAP-Proc f $_{\mathrm{f}}$ Digital Color Camera Kit Ver 4.1, Media Cybergenetics, Silver Spring, Maryland, USA) fitted on the microscope. A total of 100 cells per sample were analysed to give a representative result for the population of cells [39]. The captured comet images were analyzed by Komet software (Version 5.5, Kinetic Imaging Ltd, Bromborough, UK). The mean olive tail moment (OTM) was selected as the parameter that best reflects DNA damage (defined as the distance between the profile centers of gravity for DNA in the head and tail). OTM was measured from three independent experiments, each containing quintuplicate measures and presented as Mean \pm SEM.

\section{Statistical analyses}

The statistical analyses were performed using GraphPad Prism statistical software (GraphPad Software, San Diego, CA, USA). The significance among all groups was determined by one-way ANOVA and Bonferroni's post-hoc test was applied for multiple comparisons. The experiments were repeated for confirmation of results. The results are the average of five individual experiments. The test of homogeneity was applied to find out variation among each experiment. The data of each experiment did not differ significantly from one another and hence, all the data have been combined and means calculated. A $\mathrm{p}$ value of $<0.05$ was considered statistically significant.

\section{Results}

The results of clonogenic survival are expressed as surviving fraction in Figure 2, whereas DNA damage are expressed in Tables 1 and 2 and Figures 3 and 4 . 
Citation: Jagetia GC, et al (2015) Alteration in the Doxorubicin-Induced DNA Damage in Cultured V79 Cells by Aegle marmelos (L.) Correa

Page 4 of 9

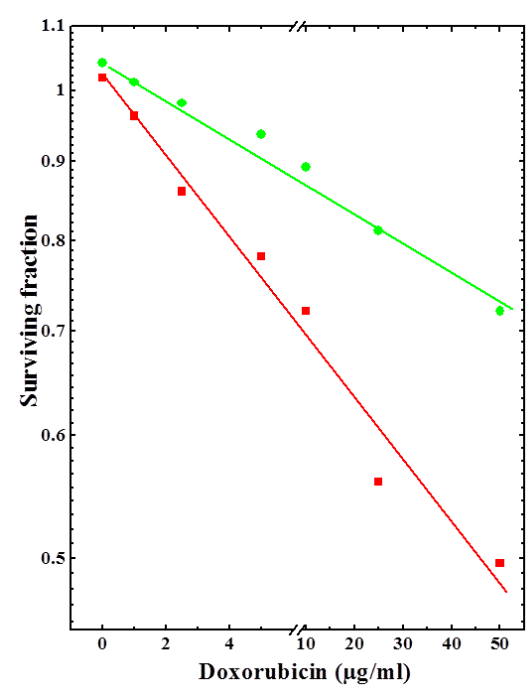

Figure 2: Alteration in the survival of V79 cells treated with 25 $\mu \mathrm{g} / \mathrm{ml}$ Aegle maramlos extract (AME) before exposure to different concentrations of doxorubicin. Squares: MEM+DOX and circles: AME+DOX
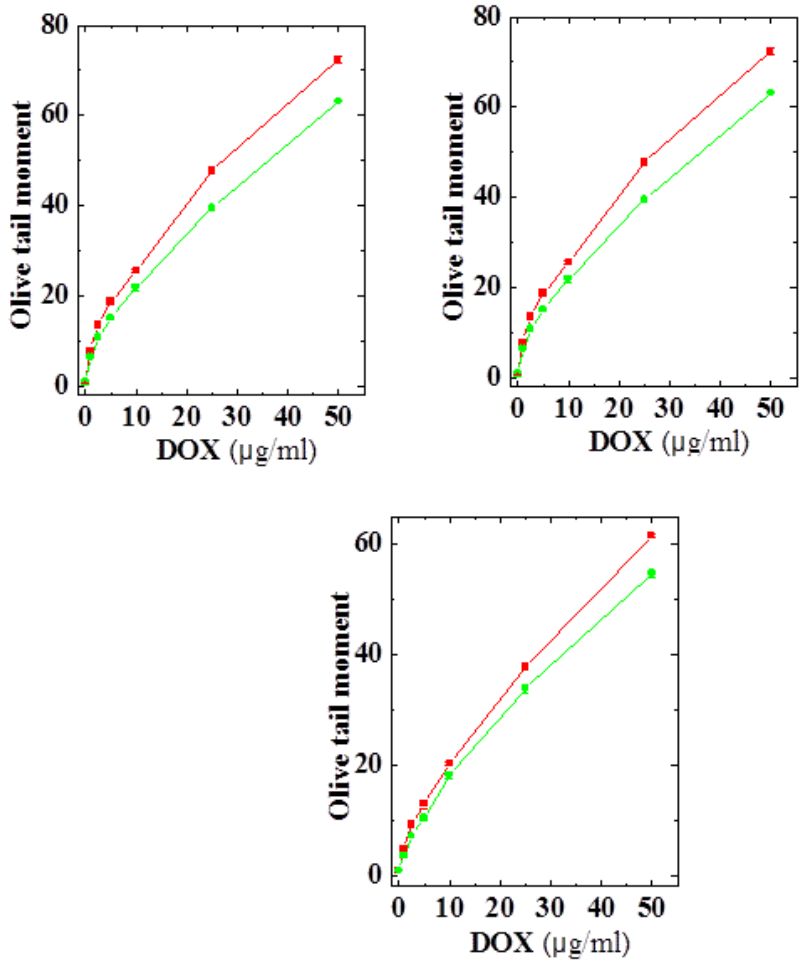

Figure 3: Effect of $25 \mu \mathrm{g} / \mathrm{ml}$ AME on the olive tail moment in V79 cells exposed to various concentration of DOX at different postDOX treatment times. Squares: MEM+DOX and circles: AME +DOX. a: $1 \mathrm{~h}, \mathrm{~b}: 4 \mathrm{~h}$ and c: $6 \mathrm{~h}$.

\section{Effect of AME on DOX-induced decline in the cell survival}

The alteration in the cytotoxicity of DOX by AME was studied by clonogenic assay. Treatment of V79 cells with different concentrations of DOX resulted in a concentration dependent decline in the cell survival as indicated by the reduction in the surviving fraction, that was lowest, i.e., 0.4 for $50 \mu \mathrm{g} / \mathrm{ml} \mathrm{DOX} \mathrm{(Figure} \mathrm{2).} \mathrm{Treatment} \mathrm{of} \mathrm{V79}$ cells with $25 \mu \mathrm{g} / \mathrm{ml}$ AME before exposure to different concentrations of DOX resulted in an elevation in the cell survival when compared with the DOX treatment alone (Figure 2).

One interesting fact was that the chemoprotective effect of AME increased with increasing concentration of DOX, where surviving fraction increased by 0.25 and 0.22 for 25 and $50 \mu \mathrm{g} / \mathrm{ml}$ DOX in AME + DOX group when compared with the concurrent DOX-treatment alone (Figure 4).

\section{Alteration in the doxorubicin-induced DNA damage by AME}

Cytotoxicity of doxorubicin is related to its capacity to induce DNA damage. In view of this we investigated whether AME will modulate the DNA strand breaks induced by doxorubicin using single cell gel electrophoresis (comet assay). The comet images are shown in Figure 1. The results are expressed as mean tail DNA and olive tail moment (OTM) in Tables 1 and 2.

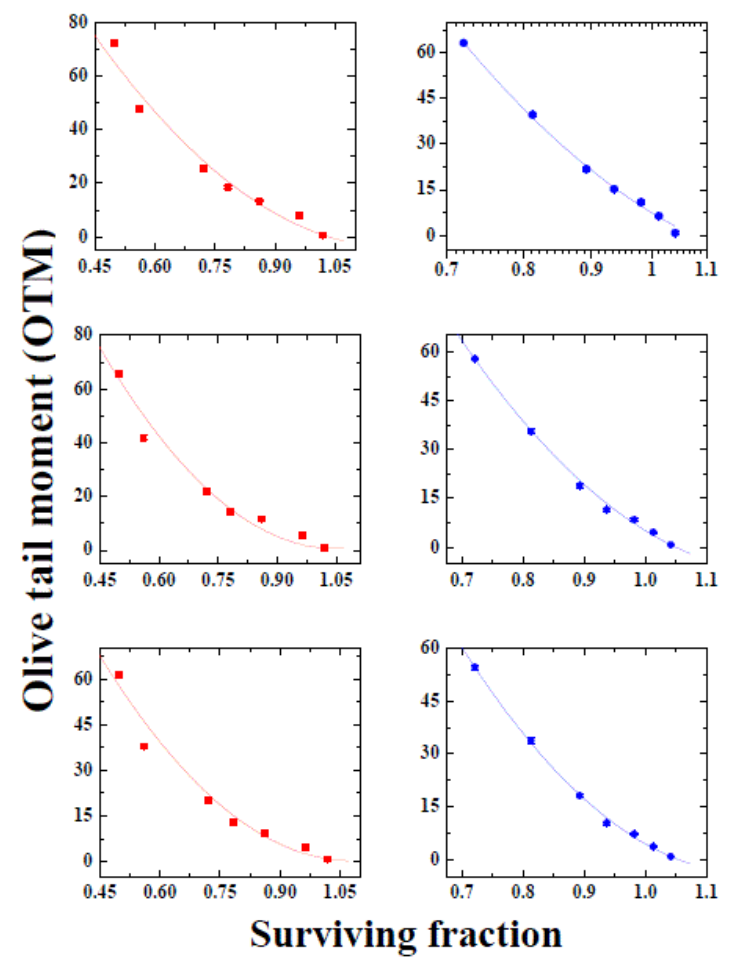

Figure 4: Correlation between DNA damage and cell survival in V79cells treated with $25 \mu \mathrm{g} / \mathrm{ml}$ AME before exposure to various concentrations of doxorubicin. Left panel DOX alone (upper $1 \mathrm{~h}$, middle $4 \mathrm{~h}$ and lower $6 \mathrm{~h}$ ). Right panel AME+DOX (upper $1 \mathrm{~h}$, middle $4 \mathrm{~h}$ and lower $6 \mathrm{~h}$ ). 
Citation: Jagetia GC, et al (2015) Alteration in the Doxorubicin-Induced DNA Damage in Cultured V79 Cells by Aegle marmelos (L.) Correa (Bael): A Comet Assay Study. Int J Neurorehabilitation 2: 1000190. doi:10.4172/2376-0281.1000190

Page 5 of 9

\section{Effect of AME on DNA repair kinetics}

Baseline DNA damage did not change significantly with assay time (Table 1). In all cases, the DNA damage of control cells remained almost constant with time, indicating that preparation and subsequent processing of the V79 cells did not introduce significant damage to cellular DNA.

\begin{tabular}{|l|l|l|l|l|l|l|}
\hline \multirow{2}{*}{$\begin{array}{l}\text { Post-treatment } \\
\text { incubation } \\
(\mathbf{h})\end{array}$} & \multicolumn{4}{l}{ Tail DNA (mean \pm SEM) } & \multicolumn{3}{l|}{ Olive Tail Moment (mean \pm SEM) } \\
\cline { 2 - 7 } & MEM & MEM+DOX & AME+DOX & MEM & MEM +DOX & AME+DOX \\
\hline 0 & $0.78 \pm 0.055$ & $25.32 \pm 0.52$ & $24.26 \pm 0.52$ & $0.78 \pm 0.055$ & $24.26 \pm 0.52$ & $23.32 \pm 0.52$ \\
\hline 0.5 & $0.91 \pm 0.056$ & $27.62 \pm 0.52$ & $25.32 \pm 0.35 \mathrm{a}$ & $0.91 \pm 0.056$ & $24.32 \pm 0.35$ & $23.38 \pm 0.52$ \\
\hline 1 & $0.90 \pm 0.052$ & $30.32 \pm 0.43$ & $26.24 \pm 0.43 \mathrm{~b}$ & $0.90 \pm 0.052$ & $25.85 \pm 0.43$ & $23.76 \pm 0.43 \mathrm{a}$ \\
\hline 2 & $0.90 \pm 0.041$ & $29.74 \pm 0.28$ & $24.25 \pm 0.36 \mathrm{~b}$ & $0.90 \pm 0.041$ & $24.25 \pm 0.36$ & $22.26 \pm 0.28 \mathrm{a}$ \\
\hline 4 & $0.92 \pm 0.035$ & $24.62 \pm 0.64$ & $22.46 \pm 0.57 \alpha \mathrm{a}$ & $0.92 \pm 0.035$ & $21.74 \pm 0.57$ & $18.86 \pm 0.64 \mathrm{ab}$ \\
\hline 6 & $0.92 \pm 0.035$ & $22.36 \pm 0.47 \alpha$ & $20.18 \pm 0.47 \alpha a$ & $0.92 \pm 0.035$ & $20.68 \pm 0.47 \alpha$ & $18.12 \pm 0.47 \mathrm{ab}$ \\
\hline 8 & $0.90 \pm 0.035$ & $18.78 \pm 0.53 \alpha$ & $19.72 \pm 0.53 \beta$ & $0.90 \pm 0.035$ & $19.58 \pm 0.53 \alpha$ & $17.84 \pm 0.53 \beta a$ \\
\hline 12 & $0.90 \pm 0.056$ & $18.52 \pm 0.55 \alpha$ & $19.36 \pm 0.55 \beta$ & $0.90 \pm 0.056$ & $18.82 \pm 0.55 \beta$ & $17.52 \pm 0.55 \beta$ \\
\hline 16 & $0.90 \pm 0.043$ & $18.04 \pm 0.37 \beta$ & $18.76 \pm 0.32 \beta$ & $0.90 \pm 0.043$ & $18.67 \pm 0.32 \beta$ & $17.36 \pm 0.37 \beta$ \\
\hline 24 & $0.84 \pm 0.033$ & $17.31 \pm 0.49 \beta$ & $16.74 \pm 0.49 \varphi$ & $0.84 \pm 0.033$ & $17.48 \pm 0.49 \beta$ & $17.31 \pm 0.49 \beta$ \\
\hline
\end{tabular}

Table 1: Alteration in the DNA damage in V79 cells exposed to $10 \mu \mathrm{g} / \mathrm{ml}$ DOX after treatment with $25 \mu \mathrm{g} / \mathrm{ml}$ of AME at various post-DOX treatment times, $\mathrm{AME}=$ Aegle marmelos extract, $\mathrm{MEM}=$ Minimum Essential Medium, DOX=Doxorubicin, SEM=Standard Error of the Mean. $\alpha=p<0.05 ; \beta=p<0.01 ; \varphi=p<0.001$ and no symbol=non-significant. (When compared with $0 h$ ), $a=p<0.05, b=p<0.01, c=p<0.001, d=p<0.0001$ and no symbol=non-significant (When compared with MEM+DOX).

V79 cells exposed to $10 \mu \mathrm{g} / \mathrm{ml}$ DOX caused a significant increase in DNA damage as evident by the increased migration of DNA into the comet tails (Table 1).

The maximum DNA damage was observed at $1 \mathrm{~h}$ post-DOX treatment that showed a subsequent decline in the DOX-induced DNA damage with assay time, which was reflected in alleviation in tail DNA and OTM. The decline in OTM indicated repair of DNA damage that was maximum up to $8 \mathrm{~h}$ post-DOX treatment and remained almost unchanged thereafter up to 24 post-DOX treatment. Treatment of V79 cells with $25 \mu \mathrm{g} / \mathrm{ml}$ AME before exposure to $10 \mu \mathrm{g} / \mathrm{ml}$ DOX caused a significant reduction in the DNA strand breaks triggered by doxorubicin at all post-DOX treatment times in AME+DOX group when compared to MEM+DOX treatment group (Table 1). The rate of DNA repair was higher in AME treated group for 1-6 h post-DOX treatment ( $\mathrm{p}<0.05$ for $4 \mathrm{~h}$ and $\mathrm{p}<0.01$ for $6 \mathrm{~h}$ ) when compared to other post-DOX treatment times as indicated by a reduced OTM and tail DNA (Table 1). AME treatment allowed early repair of DNA damage when compared to DOX treatment alone. The OTM at $4 \mathrm{~h}$ of AME pre-treated group was equal to that of $12 \mathrm{~h}$ DOX treatment alone, indicating rapid repair in the former than the latter group (Table 1).

\section{Alteration in the DNA damage response by AME}

A separate experiment was conducted to study the influence of AME on the DNA damage induced by different concentrations of DOX. Treatment of V79 cells with $0,1,2.5,5,10,25$ or $50 \mu \mathrm{g} / \mathrm{ml}$ DOX caused a concentration dependent elevation in the DNA damage measured as rise in the tail DNA and OTM at all post-DOX treatment times (Figure 3). The V79 cells treated with various concentrations of DOX showed a time-dependent decline in the DNA damage and a maximum reduction was observed at $6 \mathrm{~h}$ post-DOX treatment (Table 2). Treatment of V79 cells with $25 \mu \mathrm{g} / \mathrm{ml}$ AME before exposure to different concentrations of DOX caused a dose-dependent reduction in the DNA damage in AME+DOX group when compared with MEM + DOX treatment (Figure 3). The reduction in the DNA damage by AME was statistically significant at all concentrations of DOX, when compared with DOX-treatment alone (Table 2). The amount of DNA damage in AME+DOX group at $1 \mathrm{~h}$ post-DOX treatment was almost equal to that of DOX-treatment alone at $6 \mathrm{~h}$ post-DOX treatment indicating that DNA repair rates were higher in AME treated group than the DOX treatment alone (Table 2).

\section{Biological response}

The biological response of treatments was determined by plotting OTM on the Y-axis, whereas the surviving fraction on the $\mathrm{X}$-axis, respectively (Figure 4). A direct correlation between surviving fraction and DNA damage was apparent at all post-DOX treatment times. The increase in OTM resulted in a corresponding decline in the surviving fraction indicating an inverse correlation between DNA damage and cell survival (Figure 4). This correlation between surviving fraction and DNA damage was linear quadratic for all the post-DOX treatment times in both the DOX treatment alone and AME+DOX groups (Figure 4). 
Page 6 of 9

\begin{tabular}{|c|c|c|c|c|c|c|c|c|c|c|c|c|c|c|c|c|c|c|c|c|c|c|}
\hline \multirow[t]{3}{*}{$\begin{array}{l}\text { DOX } \\
(\mu \mathrm{g} / \mathrm{ml})\end{array}$} & \multicolumn{8}{|c|}{ Tail DNA (mean \pm SEM) } & \multicolumn{14}{|c|}{ Olive Tail Moment (mean \pm SEM) } \\
\hline & \multicolumn{2}{|l|}{$1 \mathrm{~h}$} & & \multicolumn{3}{|l|}{$4 \mathrm{~h}$} & \multicolumn{4}{|l|}{$6 \mathrm{~h}$} & \multicolumn{4}{|l|}{$1 \mathrm{~h}$} & \multicolumn{4}{|l|}{$4 \mathrm{~h}$} & \multicolumn{4}{|l|}{$6 \mathrm{~h}$} \\
\hline & $\begin{array}{l}\text { MEM } \\
\text { DOX }\end{array}$ & $\begin{array}{l}\text { AME } \\
\text { DOX }\end{array}$ & & $\begin{array}{l}\text { MEM } \\
\text { DOX }\end{array}$ & $\begin{array}{l}\text { AME } \\
\text { DOX }\end{array}$ & + & $\begin{array}{l}\text { MEM } \\
\text { DOX }\end{array}$ & + & $\begin{array}{l}\text { AME } \\
\text { DOX }\end{array}$ & + & $\begin{array}{l}\text { MEM } \\
\text { DOX }\end{array}$ & + & $\begin{array}{l}\text { AME } \\
\text { DOX }\end{array}$ & + & $\begin{array}{l}\text { MEM } \\
\text { DOX }\end{array}$ & + & $\begin{array}{l}\text { AME } \\
\text { DOX }\end{array}$ & + & $\begin{array}{l}\text { MEM } \\
\text { DOX }\end{array}$ & + & $\begin{array}{l}\text { AME } \\
\text { DOX }\end{array}$ & + \\
\hline 0 & $\begin{array}{l}0.82 \\
0.02\end{array}$ & $\begin{array}{l}0.78 \\
0.04\end{array}$ & & $0.84 \pm 0.04$ & $\begin{array}{l}0.81 \\
0.04\end{array}$ & \pm & $\begin{array}{l}0.78 \\
0.024\end{array}$ & & $\begin{array}{l}0.76 \\
0.054\end{array}$ & \pm & $0.76 \pm 0.03$ & & $\begin{array}{l}0.76 \\
0.057\end{array}$ & \pm & $0.75 \pm 0.04$ & & $\begin{array}{l}0.76 \\
0.038\end{array}$ & \pm & $\begin{array}{l}0.76 \\
0.049\end{array}$ & & $\begin{array}{l}0.75 \\
0.04\end{array}$ & \pm \\
\hline 1 & $\begin{array}{ll}12.32 & \pm \\
0.36 a & \end{array}$ & $\begin{array}{ll}9.28 & \pm \\
0.18 a\end{array}$ & & $\begin{array}{l}9.52 \\
0.14 \mathrm{ab}\end{array}$ & $\begin{array}{l}7.98 \\
0.526 a\end{array}$ & & $\begin{array}{l}4.86 \\
0 . .34 a b\end{array}$ & & $\begin{array}{l}6.21 \\
0.11 \mathrm{ab}\end{array}$ & \pm & $7.86 \pm 0.2$ & & $\begin{array}{l}6.32 \\
0.18 b\end{array}$ & \pm & $5.54 \pm 0.36$ & & $\begin{array}{l}4.62 \\
0.24\end{array}$ & & $\begin{array}{l}4.63 \\
0.16\end{array}$ & & $\begin{array}{l}3.58 \\
0.26 \mathrm{~b}\end{array}$ & \\
\hline 2.5 & $\begin{array}{ll}17.62 & \pm \\
0.36 \mathrm{~b} & \end{array}$ & \begin{tabular}{|l|}
14.48 \\
$0.38 \mathrm{~b}$
\end{tabular} & & $\begin{array}{l}13.67 \\
0.32 \mathrm{bb}\end{array}$ & \begin{tabular}{|l|}
13.08 \\
$0.83 b$
\end{tabular} & \pm & $\begin{array}{l}11.84 \\
0.48 \mathrm{bb}\end{array}$ & \pm & $\begin{array}{l}9.42 \\
0.46 \mathrm{bb}\end{array}$ & \pm & $\begin{array}{l}13.54 \\
0.46\end{array}$ & \pm & $\begin{array}{l}10.84 \\
0.64 \mathrm{~b}\end{array}$ & \pm & $\begin{array}{l}11.62 \\
0.74\end{array}$ & & $\begin{array}{l}8.48 \\
0.28 b\end{array}$ & \pm & $\begin{array}{l}9.28 \\
0.56\end{array}$ & \pm & $\begin{array}{l}7.14 \\
0.32 b\end{array}$ & \pm \\
\hline 5 & $\begin{array}{ll}21.62 \\
0.42 f\end{array}$ & \begin{tabular}{|ll}
18.92 & \pm \\
$0.28 f$ &
\end{tabular} & & $\begin{array}{l}19.21 \\
0.48 \mathrm{fb}\end{array} \quad \pm$ & $\begin{array}{l}17.63 \\
0.29 f\end{array}$ & \pm & $\begin{array}{l}14.76 \\
0.52 \mathrm{fb}\end{array}$ & & $\begin{array}{l}13.32 \\
0.86 \mathrm{fb}\end{array}$ & \pm & $\begin{array}{l}18.74 \\
0.58\end{array}$ & \pm & $\begin{array}{l}15.18 \\
0.26 \mathrm{c}\end{array}$ & \pm & $\begin{array}{l}14.34 \\
0.34\end{array}$ & & $\begin{array}{l}11.52 \\
0.42 b\end{array}$ & \pm & $\begin{array}{l}12.86 \\
0.76\end{array}$ & & $\begin{array}{l}10.28 \\
0.42 a\end{array}$ & \pm \\
\hline 10 & $\begin{array}{ll}29.34 \\
0.21 f\end{array}$ & \begin{tabular}{|l|}
27.59 \\
$0.82 f$
\end{tabular} & & $\begin{array}{l}25.38 \\
0.84 \mathrm{fb}\end{array}$ & \begin{tabular}{|l|}
23.58 \\
$0.74 f$
\end{tabular} & \pm & $\begin{array}{l}23.24 \\
0.34 \mathrm{fb}\end{array}$ & \pm & $\begin{array}{l}21.28 \\
0.52 \mathrm{fb}\end{array}$ & \pm & $\begin{array}{l}25.55 \\
0.32\end{array}$ & \pm & $\begin{array}{l}21.76 \\
0.73 c\end{array}$ & \pm & $\begin{array}{l}21.72 \\
0.56\end{array}$ & & $\begin{array}{l}18.86 \\
0.64 b\end{array}$ & \pm & $\begin{array}{l}20.18 \pm 0 \\
38\end{array}$ & 0. & $\begin{array}{l}18.12 \\
0.51 \mathrm{~b}\end{array}$ & \\
\hline 25 & $\begin{array}{ll}54.86 & \pm \\
0.58 f & \end{array}$ & $\begin{array}{l}49.38 \\
0.63 f\end{array}$ & & $\begin{array}{l}49.53 \\
0.38 \mathrm{fc}\end{array} \quad \pm$ & $\begin{array}{l}41.77 \\
0.46 f\end{array}$ & \pm & $\begin{array}{l}33.62 \\
0.84 f \mathrm{c}\end{array}$ & \pm & $\begin{array}{l}29.32 \\
0.74 \mathrm{c}\end{array}$ & & $\begin{array}{l}47.72 \\
0.73\end{array}$ & & $\begin{array}{l}39.53 \\
0.50 \mathrm{~d}\end{array}$ & \pm & $\begin{array}{l}41.77 \\
0.84\end{array}$ & & $\begin{array}{l}35.53 \\
0.74 c\end{array}$ & \pm & $\begin{array}{l}37.82 \\
0.45\end{array}$ & & $\begin{array}{l}33.74 \\
0.72 \mathrm{c}\end{array}$ & \pm \\
\hline 50 & $\begin{array}{ll}86.32 & \pm \\
0.41 f & \end{array}$ & $\begin{array}{l}79.96 \\
0.86 f\end{array}$ & & $\begin{array}{l}78.74 \\
0.72 \mathrm{fc}\end{array}$ & \begin{tabular}{|l|}
69.42 \\
$0.28 f$
\end{tabular} & \pm & $\begin{array}{l}75.28 \\
0.24 \mathrm{fc}\end{array}$ & & $\begin{array}{l}71.76 \\
0.42 \mathrm{fc}\end{array}$ & & $\begin{array}{l}72.41 \\
0.64\end{array}$ & & $\begin{array}{l}63.18 \\
0.21 d\end{array}$ & & $\begin{array}{l}65.64 \\
0.38\end{array}$ & & $\begin{array}{l}57.82 \\
0.26 \mathrm{c}\end{array}$ & \pm & $\begin{array}{l}61.48 \\
0.32\end{array}$ & & $\begin{array}{l}54.66 \\
0.64 d\end{array}$ & \\
\hline
\end{tabular}

Table 2: Effect of $25 \mu \mathrm{g} / \mathrm{ml}$ AME on the DNA damage induced by different concentration of DOX at various times in V79 cells, AME=Aegle marmelos I, MEM=Minimum Essential Medium, DOX=Doxorubicin, SEM=Standard Error of the Mean. $\alpha=p<0.05 ; \beta=p<0.01 ; \varphi=p<0.001$ and no symbol=non-significant. (When compared with $0 \mathrm{~h}$ ), $\mathrm{a}=\mathrm{p}<0.05, \mathrm{~b}=\mathrm{p}<0.01, \mathrm{c}=\mathrm{p}<0.001, \mathrm{~d}=\mathrm{p}<0.0001$ and no symbol=non-significant $($ When compared with MEM+DOX)

\section{Discussion}

Chemotherapy plays a major role in treating various cancers especially to control advanced stages of malignancies in clinical settings [41]. Most of these chemotherapeutic agents exhibit severe normal toxicity, and cause undesirable side effects. The clinical use of anthracyclines like DOX induces life threatening cardiomyopathy and congestive heart failure, which is a major hindrance for optimum use of DOX [42]. Clinical doses of doxorubicin and other anticancer drugs, which are sufficient to kill tumor cells are often toxic to normal cells/ tissues and lead to undesirable side effects like myelosuppression, neutropenia, cardiomyopathy, nausea, vomiting and induction of secondary tumors $[17,18]$. Pharmacological agents that protect myeloid and lymphoid systems from the suppressive effects of radiation or chemotherapy may be beneficial in attenuating the side effects induced by a standard therapy regimen/s. This might also allow drug/s dose escalation to effectively control the neoplastic diseases. Therefore, it is essential to screen pharmacological agents that can protect normal cells against DOX-induced cumulative toxicity. Plants by virtue of their wide usage in the traditional medicine and less toxic implications have been drawing attention of researchers around the world. Natural products may be very useful, if they are found to protect against the deleterious effects of these antineoplastic agents on the normal cells/ tissues, because of their biological origin and lesser toxic implications. Also they are widely acceptable, would not put an extra foreign substance into the body and can be safely manipulated for human use without toxic manifestations [31]. Most of the chemotherapeutic drugs including DOX kill neoplastic cells by triggering DNA damage into cells $[43,44]$, which can be easily estimated by comet assay $[34,39,40,45]$. Doxorubicin is a topoisomerase-II inhibitor that exerts its cytotoxic effects by stabilizing
DNA double strand breaks in the cellular genome [46]. Therefore, we have investigated the ability of AME to protect against DOX-induced DNA strand breaks and repair in V79 cells exposed to different concentrations of DOX.

Exposure of V79 cells to DOX caused a significant DNA damage as evidenced by increased tail DNA and Olive tail moment, which is in agreement with earlier reports [7,14,15,47-49]. Similarly, idarubicin has been reported to cause DNA strand breaks in a concentrationdependent manner in in vitro [50]. This increased DNA damage by doxorubicin may due to induction of 8-OHdG DNA adducts [23] and also due to inhibition of topoisomerase II. Doxorubicin diffuses across the cell membrane and intercalates between DNA base pairs and target topoisomerase II, resulting in DNA double strand breaks. Doxorubicin also generate free radicals that induce DNA single strand breaks, alkali labile sites and oxidized DNA bases [46,50-53].

Treatment of V79 cells with $25 \mu \mathrm{g} / \mathrm{ml}$ AME caused a timedependent decline in the DOX-induced DNA damage as evidenced by decreased tail DNA and Olive tail moment at different post-DOX treatment times. The highest DNA damage was observed at $1 \mathrm{~h}$ postDOX treatment that continued to decline with assay time indicating triggering of repair processes with a maximum repair at $8 \mathrm{~h}$ post-DOX treatment. AME pre-treatment hastened the rate of repair indicated by reduced DNA in comet tails and OTM. The amount of DNA damage at $4 \mathrm{~h}$ in AME+DOX group was equal to $12 \mathrm{~h}$ post-DOX treatment in MEM+DOX group. Similarly an early repair of DOX-induced DNA damage has been observed in human cells [54]. However complete repair of the DNA damage could not be restored even at the end of 24 $h$ in both the groups. An identical effect has been reported earlier where DOX-induced DNA damage assessed by comet assay was highest at $1 \mathrm{~h}$ post-DOX treatment and a complete repair could not be 
restored even after $20 \mathrm{~h}[47,55]$. A dose-dependent increase in DNA damage with increasing concentration of DOX is indicated by a significant rise in the tail DNA and OTM. Berberine a topoisomerase II inhibitor has been found to increase DNA damage in HeLa cells [45]. AME has been reported to reduce DOX-induced DNA damage in V79 cells and mice bone marrow cells earlier [14,15]. Naringin has been reported to reduce the DOX-induced 8-OHdG DNA adducts [23]. Likewise, dexazoxane (ICRF-187), cycloheximide, 3-4dihydroxybenzoic acid and lovastatin also inhibited DOX-induced DNA damage [55-58]. The reduction in the DOX-induced DNA damage by AME may be due to the presence of tannins including gallic acid and ellagic acid that have been reported to protect DNA breakages $[59,60]$.

A concentration dependent decline in clonogenicity after DOX treatment is in agreement with earlier studies, where a similar effect has been reported after DOX treatment $[15,61,62]$. The protection against DOX-induced decline in cell survival by AME is in conformation with earlier studies on 3-4-dihydroxybenzoic acid and lovastatin [55,63]. An identical effect was also observed with $10 \mu \mathrm{M}$ cycloheximide and $10 \mathrm{mM}$ WR-2721 against DOX-induced cytotoxic effect [57,64]. Several other chemicals like thiol $\mathrm{N}$-acetylcysteine (NAC) and hydrophilic flavonoids such as rutin and luteolin have been reported to reduce DOX-induced toxicity $[65,66]$.

Biological response determination gives an indication of relationship between DNA damage and cell survival and we have observed an inverse correlation between the DNA damage and cell survival in both DOX and AME+DOX groups. The surviving fraction of cells declined with the increasing DNA damage indicating that the initial lesions in DNA got stabilized and became cell lethal. An identical effect has been observed earlier [15,55]. This relationship between DNA damage and surviving fraction fitted on a linear quadratic model at all assay times in both the groups. A linear quadratic relationship has been reported for micronuclei induction and cell survival earlier [11,67].

Several putative mechanisms may be involved in DOX induced DNA damage and cytotoxicity including intercalation into DNA [51,52], stabilization of topoisomerase II-DNA complex [46,53], free radical mediated toxicity caused by redox cycling of the semiquinone radical or formation of reactive oxygen species by the DOX iron complex [68-70]. DOX has been reported to be metabolically activated to a free radical state and interacts with molecular oxygen to generate superoxide radicals $[70,71]$. The superoxide radicals can react with hydrogen peroxide to form highly reactive hydroxyl radicals via the iron catalyzed Haber-Weiss reaction. Secondarily derived hydroxyl radicals can cause protein and DNA damage and initiate lipid peroxidation [73]. The inhibition of topoisomerase II by DOX may have caused stabilization of transient DNA strand breaks leading to increased DNA damage and subsequently the cell death in the present study. DOX has been reported to trigger the transcriptional activation of NF- $\kappa B$ as a response to DNA damage and elevate COX-II expression $[74,75]$. Our earlier study has reported increased PARP activity by DOX in vivo that was directly correlated with the increased formation of 8-OHdG DNA adducts that may have subsequently converted into strand breaks [23].

The exact mechanism of chemoprotective effect of AME is not known, several putative mechanisms may have contributed in various ways to reduce DOX-induced DNA damage and cytotoxicity in V79 cells. AME may have scavenged DOX-induced free radicals and/or inhibited iron-DOX complex formation. This contention is supported by our earlier reports, where AME has been reported to scavenge free radicals in vitro and in vivo $[33,76]$. Attrition in DOX-induced DNA damage may be atrributed to the restoration of topoisomerase II activity by AME. The attenuation of DOX-induced lipid peroxidation by AME may have reduced the DNA damage and increased the survival in the AME+DOX group. AME has been reported to increase glutathione and reduce lipid peroxidation earlier [31,32]. The suppression of transcriptional activation of NF- $\kappa \mathrm{B}, \mathrm{COX}-\mathrm{II}$ and PARP genes by AME may have also contributed in various ways to reduce DOX-induced DNA damage. AME may have also upregulated the transcription of Nrf2 gene leading to reduced DNA damage and cell survival since DOX has been reported to alleviate its expression [77]. AME may have also suppressed the DOX-induced 8-OHdG DNA adducts thereby reducing the DNA damage and increasing the cell survival.

\section{Conclusion}

Our study indicates that AME inhibited DOX-induced DNA damage and subsequently the cytotoxicity. The reduction in DNA damage and cytotoxicity by AME may be due to free radical scavenging, iron chelation, restoration of topoisomerase II activity, inhibition of ROS generation and increased antioxidants status. The AME may have suppressed the transcription of NF- $\kappa B$, COX-II and PARP genes accompanied by the upregulation of Nrf2 gene that may have increased the antioxidant status of DOX-treated cells and protected against cytotoxicity and DOX-induced DNA damage.

\section{Acknowledgement}

The authors are thankful to the Indian council of Medical Research, Govt. of India for financial support to carry out this study.

\section{References}

1. Arcamone F, Cassinelli G, Fantini G, Grein A, Orezzi P, et al., (1969) Adriamycin, 14-hydroxydaunomycin, a new antitumor antibiotic from $S$. peucetius var. caesius. Biotechnol Bioeng 9: 1101-1110.

2. O'Bryan RM, Baker LH, Gottlieb JE, Rivkin SE, Balcerzak SP, et al. (1977) Dose response evaluation of adriamycin in human neoplasia. Cancer 39: 1940-1948.

3. Goldin A, Sandberg JS, Henderson ES, Newman JW, Frei E 3rd, et al. (1971) The chemotherapy of human and animal acute leukemia. Cancer Chemother Rep 55: 309-505.

4. Martin WM, McNally NJ (1980) Cytotoxicity of adriamycin to tumour cells in vivo and in vitro. Br J Cancer 42: 881-889.

5. Tacar O, Sriamornsak P, Dass CR (2013) Doxorubicin: an update on anticancer molecular action, toxicity and novel drug delivery systems. J Pharm Pharmacol 65: 157-170.

6. Bean CL, Armstrong MJ, Galloway SM (1992) Effect of sampling time on chromosome aberration yield for 7 chemicals in Chinese hamster ovary cells. Mutat Res 265: 31-44.

7. Delvaeye M, Verovski V, De Neve W, Storme G (1993) DNA breakage, cytotoxicity, drug accumulation and retention in two human ovarian tumor cell lines AZ224 and AZ364 treated with adriamycin, modulated by verapamil. Anticancer Res 13: 1533-1538.

8. Shan K, Lincoff AM, Young JB (1996) Anthracycline-induced cardiotoxicity. Ann Intern Med 125: 47-58.

9. Jagetia GC, Nayak V (1996) Micronuclei-induction and its correlation to cell survival in HeLa cells treated with different doses of adriamycin. Cancer Lett 110: 123-128. 
10. Jagetia GC, Nayak V, Vidyasagar MS (1998) Evaluation of the antineoplastic activity of guduchi (Tinospora cordifolia) in cultured HeLa cells. Cancer Lett 127: 71-82.

11. Jagetia GC, Aruna R (2000) Correlation between cell survival and micronuclei-induction in HeLa cells treated with adriamycin after exposure to various doses of gamma-radiation. Toxicol Lett 115: 183-193.

12. Jagetia GC, Nayak V (2000) Effect of doxorubicin on cell survival and micronuclei formation in HeLa cells exposed to different doses of gamma-radiation. Strahlenther Onkol 176: 422-428.

13. Dhawan A, Kayani MA, Parry JM, Parry E, Anderson D (2003) Aneugenic and clastogenic effects of doxorubicin in human lymphocytes. Mutagenesis 18: 487-490.

14. Venkatesh P, Shantala B, Jagetia GC, Rao KK, Baliga MS (2007) Modulation of doxorubicin-induced genotoxicity by Aegle marmelos in mouse bone marrow: a micronucleus study. Integr Cancer Ther 6: 42-53.

15. Jagetia GC, Rao SK (2015) Bael, Aegle marmelos (L.) Correa, an Indian medicinal plant protects V79 cells against the genotoxic effect of doxorubicin. Int J Genet Mol Biol 7: 32-46.

16. Baker ES, Connor TH (1996) Monitoring occupational exposure to cancer chemotherapy drugs. Am J Health Syst Pharm 53: 2713-2723.

17. Pendleton M, Lindsey RH Jr, Felix CA, Grimwade D, Osheroff N (2014) Topoisomerase II and leukemia. Ann N Y Acad Sci 1310: 98-110.

18. Singal PK, Iliskovic N, Li T, Kumar D (1997) Adriamycin cardiomyopathy: pathophysiology and prevention. FASEB J 11: 931-936.

19. Jagetia GC, Venkatesh P (2015b) An Indigenous plant Bael (Aegle marmelos (L.) Correa) Extract Protects Against the Doxorubicin-Induced Cardiotoxicity in Mice. Biochem. Physiol. 4:3.

20. Chatterjee K, Zhang J, Honbo N, Karliner JS (2010) Doxorubicin cardiomyopathy. Cardiology 115: 155-162.

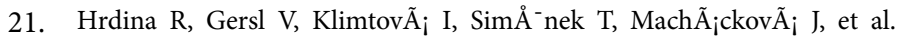
(2000) Anthracycline-induced cardiotoxicity. Acta Medica (Hradec Kralove) 43: 75-82.

22. Rice-Evans CA, Miller NJ, Bolwell PG, Bramley PM, Pridham JB (1995) The relative antioxidant activities of plant-derived polyphenolic flavonoids. Free Radic Res 22: 375-383.

23. Jagetia GC, Reddy TK (2014) The grape fruit flavonone naringin protects mice against doxorubicin-induced cardiotoxicity. J Mol Biochem 3:34-49.

24. Rekka E, Kourounakis PN (1991) Effect of hydroxyethyl rutosides and related compounds on lipid peroxidation and free radical scavenging activity. Some structural aspects. J Pharm Pharmacol 43: 486-491.

25. van Acker SA, van den Berg DJ, Tromp MN, Griffioen DH, van Bennekom WP, et al. (1996) Structural aspects of antioxidant activity of flavonoids. Free Radic Biol Med 20: 331-342.

26. Cordell GA (2011) Sustainable medicines and global health care. Planta Med 77: 1129-1138.

27. Sharma RK, Dash B (1998) Carka Samhita Volume II. Chowkamba Sanskrit Series Office, Varanasi, India

28. CHEMEXCIL (1992) Selected medicinal plants of India. Basic chemicals, Pharmaceutical and Cosmetic Export Promotion Council, Bombay 400 039, India.

29. Nadkarni AK (1976) Indian Materia Medica, Ed 3. Popular Press Ltd. Mumbai, India

30. Singh RP, Banerjee S, Rao AR (2000) Effect of Aegle marmelos on biotransformation enzyme systems and protection against free-radicalmediated damage in mice. J Pharm Pharmacol 52: 991-1000.

31. Jagetia GC, Venkatesh P, Baliga MS (2004) Evaluation of the radioprotective effect of bael leaf (Aegle marmelos) extract in mice. Int J Radiat Biol 80: 281-290.

32. Jagetia GC, Venkatesh P (2005) Radioprotection by oral administration of Aegle marmelos (L.) Correa in vivo. J Environ Pathol Toxicol Oncol 24: 315-332.

33. Jagetia GC, Venkatesh P, Baliga MS (2003) Evaluation of the radioprotective effect of Aegle marmelos (L.) Correa in cultured human peripheral blood lymphocytes exposed to different doses of gammaradiation: a micronucleus study. Mutagenesis 18:387-393.
34. Collins AR (2014) Measuring oxidative damage to DNA and its repair with the comet assay. Biochim Biophys Acta 1840: 794-800.

35. Hartmann A, Elhajouji A, Kiskinis E, Poetter F, Martus H, et al. (2001) Use of the alkaline comet assay for industrial genotoxicity screening: comparative investigation with the micronucleus test. Food Chem Toxicol 39: 843-858.

36. Puck TT, Marcus PI (1955) A rapid method for viable cell titration and clone production with hela cells in tissue culture: the use of $\mathrm{x}$-irradiated cells to supply conditioning factors. Proc Natl Acad Sci U S A 41: 432-437.

37. Singh NP, McCoy MT, Tice RR, Schneider EL (1988) A simple technique for quantitation of low levels of DNA damage in individual cells. Exp Cell Res 175: 184-191.

38. Olive PL, Banáth JP (2006) The comet assay: a method to measure DNA damage in individual cells. Nat Protoc 1: 23-29.

39. Azqueta A, Collins AR (2013) The essential comet assay: a comprehensive guide to measuring DNA damage and repair. Arch Toxicol 87: 949-968.

40. Jagetia A, Jagetia GC, Jha S (2007) Naringin, a grapefruit flavanone, protects V79 cells against the bleomycin-induced genotoxicity and decline in survival. J Appl Toxicol 27: 122-132.

41. Kinghorn AD, Farnsworth NR, Soejarto DD, Cordell GA, Swanson SM, et al. (2003) Novel Strategies for the Discovery of Plant-Derived Anticancer Agents. Pharmaceut Biol. 41(Suppl) 53-67.

42. Minotti G, Recalcati S, Menna P, Salvatorelli E, Corna G, et al. (2004) Doxorubicin cardiotoxicity and the control of iron metabolism: quinonedependent and independent mechanisms. Methods Enzymol 378: 340-361.

43. Hurley LH (2002) DNA and its associated processes as targets for cancer therapy. Nat Rev Cancer 2: 188-200.

44. L'Ecuyer T, Sanjeev S, Thomas R, Novak R, Das L, et al. (2006) DNA damage is an early event in doxorubicin-induced cardiac myocyte death. Am J Physiol Heart Circ Physiol 291: H1273-1280.

45. Jagetia GC, Rao SK (2015) Isoquinoline alkaloid berberine exerts its antineoplastic activity by inducing molecular DNA damage in HeLa cells: A comet assay study. Biol.Med. 7.

46. Pommier Y, Leo E, Zhang H, Marchand C (2010) DNA topoisomerases and their poisoning by anticancer and antibacterial drugs. Chem Biol 17: 421-433.

47. Tewey KM, Rowe TC, Yang L, Halligan BD, Liu LF (1984) Adriamycininduced DNA damage mediated by mammalian DNA topoisomerase II. Science 226: 466-468.

48. Sognier MA, Eberle RL, Zhang Y, Belli JA (1991) Interaction between radiation and drug damage in mammalian cells. V. DNA damage and repair induced in LZ cells by adriamycin and/or radiation. Radiat Res 126: 80-87.

49. Baumgartner A, Schmid TE, Cemeli E, Anderson D (2004) Parallel evaluation of doxorubicin-induced genetic damage in human lymphocytes and sperm using the comet assay and spectral karyotyping. Mutagenesis. 19:313-318.

50. BÅ,asiak J, Gloc E, Wo ̊oniak K, MÅ,ynarski W, Stolarska M, et al. (2002) Genotoxicity of idarubicin and its modulation by vitamins $\mathrm{C}$ and $\mathrm{E}$ and amifostine. Chem Biol Interact 140: 1-18.

51. Hynek D, Krejcova L, Zitka O, Adam V, Trnkova L, et al. (2012) Electrochemical Study of Doxorubicin Interaction with Different Sequences of Single Stranded Oligonucleotides, Part I Int J Electrochem Sci 7: 13-33.

52. Agudelo D, Bourassa P1, Bérubé G1, Tajmir-Riahi HA2 (2014) Intercalation of antitumor drug doxorubicin and its analogue by DNA duplex: structural features and biological implications. Int J Biol Macromol 66: 144-150.

53. Pommier Y, Schwartz RE, Zwelling LA, Kohn KW (1985) Effects of DNA intercalating agents on topoisomerase II induced DNA strand cleavage in isolated mammalian cell nuclei. Biochemistry 24: 6406-6410.

54. ChÅ,opkiewicz B (2002) Evaluation of adriamycin induced DNA damage and repair in human and animal cells. Acta Pol Pharm 59: 115-120. 
Citation: Jagetia GC, et al (2015) Alteration in the Doxorubicin-Induced DNA Damage in Cultured V79 Cells by Aegle marmelos (L.) Correa (Bael): A Comet Assay Study. Int J Neurorehabilitation 2: 1000190. doi:10.4172/2376-0281.1000190

Page 9 of 9

55. Bardeleben RV, Dunkern T, Kaina B, Fritz G (2002) The HMG-CoA reductase inhibitor lovastatin protects cells from the antineoplastic drugs doxorubicin and etoposide. Int J Mol Med 10: 473-479.

56. Iliakis G, Lazar W (1987) Reduction by caffeine of adriamycin-induced cell killing and DNA damage in Chinese hamster cells: correlation with modulation in intracellular adriamycin content. Cancer Res 47: 2224-2229.

57. Bonner JA, Lawrence TS (1989) Protection of doxorubicin cytotoxicity by cycloheximide. Int J Radiat Oncol Biol Phys 16: 1209-1212.

58. Deng S, Yan T, Jendrny C, Nemecek A, Vincetic M, et al. (2014) Dexrazoxane may prevent doxorubicin-induced DNA damage via depleting both topoisomerase II isoforms. BMC Cancer 14: 842.

59. Fedeli D, Berrettini M, Gabryelak T, Falcioni G (2004) The effect of some tannins on trout erythrocytes exposed to oxidative stress. Mutat Res 563: 89-96.

60. Chakraborty S, Roy M, Bhattacharya RK (2004) Prevention and repair of DNA damage by selected phytochemicals as measured by single cell gel electrophoresis. J Environ Pathol Toxicol Oncol 23: 215-226.

61. Skladanowski A, Konopa J (1993) Adriamycin and daunomycin induce programmed cell death (apoptosis) in tumour cells. Biochem Pharmacol 46: 375-382.

62. Helbig R, Speit G (1995) The pattern of adriamycin-induced mutations in V-E5 Chinese hamster cells with chromosomal instability. Mutat Res 348: $1-6$.

63. Iliakis G, Lazar W (1987) Reduction by caffeine of adriamycin-induced cell killing and DNA damage in Chinese hamster cells: correlation with modulation in intracellular adriamycin content. Cancer Res 47: 2224-2229.

64. De Graff WG, Myers LS Jr, Mitchell JB, Hahn SM (2003) Protection against Adriamycin cytotoxicity and inhibition of DNA topoisomerase II activity by 3,4-dihydroxybenzoic acid. Int J Oncol 23: 159-163.

65. al-Gharably NM (1996) Effect of probucol on the cytological and biochemical changes induced by adriamycin in Swiss albino mice. Res Commun Mol Pathol Pharmacol 94: 289-303.

66. D'Agostini F, Bagnasco M, Giunciuglio D, Albini A, De Flora S (1998) Inhibition by oral $\mathrm{N}$-acetylcysteine of doxorubicin-induced clastogenicity and alopecia, and prevention of primary tumors and lung micrometastases in mice. Int J Oncol 13: 217-224.

67. Wandl EO, Ono K, Kain R, Herbsthofer T, Hienert G, et al. (1989) Linear correlation between surviving fraction and the micronucleus frequency. Int J Radiat Biol 56: 771-775.

68. Bachur NR, Gordon SL, Gee MV, Kon H (1979) NADPH cytochrome $\mathrm{P}-450$ reductase activation of quinone anticancer agents to free radicals. Proc Natl Acad Sci USA. 76:954-957.

69. Myers CE, Mimnaugh EG, Yeh GC, Sinha BK (1988) In: Anthracyclines and Anthracenedione-based Anticancer Agents, Lown, Elsevier JW (edtr) Amsterdam, The Netherlands, 527-570.

70. Konorev EA, Kennedy MC, Kalyanaraman B (1999) Cell-permeable superoxide dismutase and glutathione peroxidase mimetics afford superior protection against doxorubicin-induced cardiotoxicity: the role of reactive oxygen and nitrogen intermediates. Arch Biochem Biophys 368: 421-428.

71. Powis G (1989) Free radical formation by antitumor quinones. Free Radic Biol Med 6: 63-101.

72. Olson RD, Mushlin PS (1990) Doxorubicin cardiotoxicity: analysis of prevailing hypotheses. FASEB J 4: 3076-3086.

73. Halliwell B, Gutteridge JMC (1989) Free Radicals in Biology and Medicine. 2nd ed. Oxford University Press, New York. 543.

74. Adderley SR, Fitzgerald DJ (1999) Oxidative damage of cardiomyocytes is limited by extracellular regulated kinases $1 / 2$-mediated induction of cyclooxygenase-2. J Biol Chem 274: 5038-5046.

75. Pletz N, Schön M, Ziegelbauer K, Emmert S, Liu N, et al., (2012) Doxorubicin-induced activation of NF-?B in melanoma cells is abrogated by inhibition of IKKß, but not by a novel IKKa inhibitor. Exp Dermatol. 21:301-314.

76. Jagetia GC, Venkatesh P. 2007. Inhibition of radiation-induced clastogenicity by Aegle marmelos (L.) correa in mice bone marrow exposed to different doses of gamma-radiation. Hum Exp Toxicol. 26:111-124.

77. Singh P, Sharma R, McElhanon K, Allen CD, Megyesi JK, et al. (2015) Sulforaphane protects the heart from doxorubicin-induced toxicity. Free Radic Biol Med 86: 90-101. 